\title{
ANALISIS RASIO LANCAR RUMAH SAKIT X
}

\author{
Marsdenia $^{1^{*}}$ \\ ${ }^{\prime}$ Program Studi Akuntansi Program Vokasi Universitas Indonesia
}

\begin{abstract}
ABSTRAK - Peningkatan efisiensi pengelolaan rumah sakit secara terus menerus merupakan pedoman pengelolaan keuangan yang mutlak harus diadopsi oleh rumah sakit mana pun. Penelitian ini bertujuan diperolehnya informasi tentang komponen yang berkontribusi terhadap terjadinya fluktuasi rasio lancar RS X tahun 2000, 2001 dan 2002. Penelitian ini menggunakan pendekatan kuantitatif dan kualitatif, dengan sumber data primer (wawancara mendalam kepada pihak terkait yaitu Direktur RS, Kepala Bagian Keuangan Wadir Adiministrasi dan Keuangan) dan data sekunder (laporan keuangan). Hasil penelitian menunjukan bahwa rasio lancar RS X masih dalam rentang normal kecuali untuk tahun 2001 yang berada dibawah standar (1.42). Rasio yang lebih sensitif, yaitu Acid Test Ratio, masih dalam rentang normal untuk tahun 2000, tetapi pada tahun 2001 dan pada tahun 2002, angka rasio berada pada tingkat dibawah rentang normal. Rasio kas juga berada pada angka dibawah normal, kecuali untuk tahun 2000. Angka perputaran piutang juga berada pada angka yang semakin kecil untuk 3 tahun ini yang memberi makna bahwa butuh waktu yang lebih lama lagi untuk menagih piutang dibandingkan dengan rentang normal hari tertagihnya piutang yaitu antara 14 sampai dengan 20 hari. Untuk angka rasio perputaran persediaan RS X berada dibawah angka rasio normal (24-32 kali pembelian per tahun). Sedangkan hari rata-rata persediaan tersimpan digudang adalah selama $16-21$ hari. Nilai rasio lancar diperoleh dari perbandingan asset lancar dengan kewajiban lancar, dimana secara angka/nominal rasio lancar RS X pada tahun 2002 pada rentang normal, 1,5-2,00 tetapi angka ini memiliki nilai riil yang sebaliknya. Hal ini karena saldo piutang pasien jaminan dinilai pada angka yang terlalu tinggi begitu juga dengan piutang pasien non jaminan/pasien umum/pasien dengan bayar sendiri. Berdasarkan penelitian ini, manajemen RS X memiliki berbagai solusi untuk mengatasi masalah likuiditas yang ditandai dengan menurunnya rasio lancar dan berada pada rentang dibawah normal. Ada beberapa usulan yang bisa diimplementasikan oleh manajemen, yaitu melakukan pengendalian atas pengeluaran kas keluar dan kas masuk, melakukan evaluasi kembali atas kebijakan pemberian piutang kepada pasien, reformasi prosedur persediaan obat.
\end{abstract}

Kata kunci: Rasio lancar, kas, piutang pasien, persediaan, kewajiban lancar.

ABSTRACT - Increasing the efficiency of hospital management sustainability is an ongoing financial management guidelines that absolutely must be adopted by any hospital. This study aims at obtaining information about the components that contribute to the fluctuations of the current ratio Hospital $X$ between 2000, 2001 and 2002. This study used quantitative and qualitative approaches, with the primary data source (in-depth interviews to the relevant parties ie Hospital Director, Chief Financial Officer and Vice Director Adiministrasi Finance) and the secondary data source include financial statements. The research shows that $R S X$ 's current ratio are still in a normal range except in the year of 2001 was below the standard (1.42). The more sensitive ratio, Acid Test Ratio, is still in normal range in the year of 2000, but in the year of 2001, and 2002, the ratios are in the lowest bend of the normal range. Cash Ratios for many years are also in the lowest bend except for the year of 2000, Receivable turn over ratios for the last three years go smaller showing that receivables took longer time to collect, the normal range for receivable turn over is 14 up to 20 days. Inventory turn over ratios are below the standard range (24-32 times per year), the average inventory held in warehouse 
is between 16 up to 21 days. The value of current ratio is got from comparison between current assets and current liabilities. Nominally, RS X's current ratio in 2002 is in the state bend, namely, 1.5-2.00, in the real term, the ratio showes on contradictory pictures. The reasons are a) Guaranteed Receivables are valued above the normal practice (overstated) b) overstated of Non Guaranteed receivables/Personal Receivables.

Based on this research, the author thinks that there are some rooms for RS X's management to fit their current ratio problem. There are several suggestions that the management can adopt, namely controlling cash outflow and cash inflow, reevaluating receivables policy, reforming the supply of inventories (medicine) procedures.

Keywords: Current ratio, cash, patient receivables, inventory, current liabilities.

\section{PENDAHULUAN}

\section{Latar Belakang}

Peningkatan efisiensi pengelolaan rumah sakit secara terus menerus merupakan pedoman pengelolaan keuangan yang mutlak harus diadopsi oleh rumah sakit mana pun, dimana efisiensi yang tinggi akan meningkatkan keunggulan kompetitif dan peningkatan pendaptan dan akhirnya meningkatkan kemampuan keuangan rumah sakit (RS) untuk mensejahterakan anggotanya (Setiawan, 1996).

Statistik perkembangan RS Swasta memperlihatkan bahwa telah terjadi pertumbuhan yang sangat pesat baik itu untuk jenis RS umum mau pun RS khusus seperti RS Khusus Jiwa, Kusta atau Tuberculosis. (Depkes RI, 1998), semakin besarnya peranan pelayanan kesehatan rumah sakit oleh sektor swasta ditandai dengan tingkat pertumbuhan yang rumah sakit swasta sebesar $142 \%$ untuk jenis pelayanan umum.

RS X merupakan rumah sakit swasta yang setahap demi setahap berusaha untuk meningkatkan mutu pelayanannya, dengan menambah sarana penunjang medis, jumlah tempat tidur (TT), serta alat-alat medis sehingga sekarang telah mempunyai 126 TT, termasuk tipe madya (kelas C). RS X telah menjalin kerjasama dengan instansi-instansi se Jabotabek, telah menerima sertifikasi Akreditasi penuh untuk lima standar pelayanan rumah sakit dari Depkes pada 1 September 1999.

Dari laporan keuangan RS X periode 2000 s/d 2002 untuk analisis rasio likuiditas, terlihat bahwa cenderung terjadi penurunan yang cukup lebar, terutama untuk angka rasio lancar tahun 2001 yang turun hampir setengah dari angka rasio lancar untuk tahun 2000. Begitu juga dengan angka rasio cair, rasio kas dan rasio-rasio likuiditas lainnya cenderung terjadi penurunan, yang segera harus dicermati penyebabnya. Memang rasio lancar lebih menggambarkan secara komprehensif dari kondisi likuiditas. Dimana rasio cair dan rasio kas lebih menggambarkan sensitivitas dari kemampuan likuiditas dari RS karena rasio cair diperoleh dari mengeluarkan komponen persediaan dari komponen harta lancar dari formula rasio lancar, sedangkan rasio kas adalah mengeluarkan komponen piutang dari komponen harta lancar (neumann, 1995). Rasio lancar diperoleh dari 
perbandingan antara harta lancar dengan kewajiban lancar dengan ukuran baku 1.752.75 (Sjaaf, 2000). Terlihat pada rasio lancar RS X yang sudah tidak dalam ukuran baku yaitu sebesar 1.42 pada tahun 2001.

Dari Kinerja Pelayanan RS X secara kasar terlihat bahwa untuk BOR delapan tahun terakhir cenderung terjadi penurunan terus sampai tahun 2002 (Tabel 1.1). Penurunan antara lain karena faktor eksternal rumah sakit yang tidak bias diintervensi yaitu terjadinya krisis moneter dan krisis global.

Tabel 1.1

Kinerja pelayanan RS X 8 tahun $(1995$ - 2002)

\begin{tabular}{|l|l|l|l|l|l|l|l|l|}
\hline Indikator & $\mathbf{1 9 9 5}$ & $\mathbf{1 9 9 6}$ & $\mathbf{1 9 9 7}$ & $\mathbf{1 9 9 8}$ & $\mathbf{1 9 9 9}$ & $\mathbf{2 0 0 0}$ & $\mathbf{2 0 0 1}$ & $\mathbf{2 0 0 2}$ \\
\hline BOR & 70,45 & 66,71 & 69,00 & 53,27 & 54,00 & 67,97 & 68,40 & 65,50 \\
\hline LOS & 4,06 & 4,14 & 3,81 & 3,69 & 3,70 & 3,48 & 3,38 & 3,45 \\
\hline BTO & 67,55 & 62,02 & 66,50 & 51,80 & 53,43 & 68,42 & 71,06 & 68,50 \\
\hline TOI & 1,60 & 1,97 & 1,68 & 3,29 & 3,14 & 1,71 & 1,62 & 1,84 \\
\hline NDR & 0,9 & 1 & 0,89 & 1,61 & 1,36 & 1,48 & 1,37 & 1,32 \\
\hline TT & 123 & 121 & 121 & 127 & 127 & 126 & 126 & 126 \\
\hline
\end{tabular}

Sumber: bagian Informatika RS X

\section{Pokok Masalah}

a. Fluktuasi saldo kas, bank dan deposito 2000, 2001, 2002 yang cukup lebar

b. Fluktuasi saldo piutang tahun 2000, 2001 dan 2002 yang cukup lebar dan saldo piutang yang besar

c. Fluktuasi saldo perediaan obat tahun 2000, 2001, 2002 yang cukup lebar dan saldo persediaan obat yang besar

\section{a. Pertanyaan penelitian}

1. Komponen apa saja yang berkontribusi terhadap terjadinya fluktuasi kas, bank, deposito serta apa/bagaimana solusi pengelolaan kas, bank, deposito?
2. Komponen apa saja yang berkontribusi terhadap terjadinya fluktuasi saldo piutang dan besarnya saldo piutang, apa/bagaimana solusi pengelolaan piutang?

3. Komponen apa saja yang berkontribusi terhadap terjadinya fluktuasi saldo persediaan dan besarnya saldo persediaan, apa/bagaimana solusi pengelolaan persediaan?

\section{Tujuan}

\section{a. Tujuan Umum}

Diperolehnya informasi tentang komponen yang berkontribusi terhadap terjadinya fluktuasi 
rasio lancar RS X tahun 2000, 2001 dan 2002 sehingga bisa memberikan masukan kepada pihak manajemen agar bisa menjaga rasio lancar dalam batas yang aman dalam rangka mempertahankan kelangsungan RS X dimasa yang akan dating.

\section{b. Tujuan Khusus}

- Diketahuinya informasi tentang komponen yang berkontribusi terhadap terjadinya fluktuasi kas, bank, deposito dan solusi pengelolaan kas, bank, deposito

- Diketahuinya informasi tentang komponen yang berkontribusi terhadap terjadinya fluktuasi piutang dan solusi pengelolaan piutang

- Diketahuinya informasi tentang komponen yang berkontribusi terhadap terjadinya persediaan obat dan solusi pengelolaan persediaan obat

\section{Metodologi Penelitian}

\section{a. Kerangka Konsep}

Fluktuasi rasio lancar RS X untuk tahun 2000, 2001 dan 2002 bisa dianalisis dengan pendekatan sistem untuk melihat rasio lancar sebagai suatu indikator kinerja RS secara komprehensif/menyeluruh.

Menurut Neumann (1995), rasio lancar diperoleh dari aktiva lancar dibagi dengan kewajiban lancar yang menggambarkan kemampuan rumah sakit didalam memenuhi kewajiban jangka pendeknya yang jatuh tempo. Dimana Aktiva lancar rumah sakit terdiri dari kas, piutang, persediaan dan kewajiban lancar terdiri dari kewajiban kepada vendor dan uang muka pasien.

a. input : Penderita yang berobat jalan dan menginap, tenaga medis, para medis dan non medis (Man), SDU (Sumber Daya Uang), Metode/Prosedur dan peralatan medis dan non medis/mesin/Komputerisasi (sarana prasarana) (Modifikasi PERDHAKI, 1992)

b. Proses : dimana untuk proses diambil dari kegiatan yang ada di rumah sakit yang akan menghasilkan penerimaan kas, pengeluaran kas, pre-admission, admission, inhouse, Collecting, Write-off, Permintaan obat/Kebutuhan. Pengadaan/Pemesanan, Penerimaan Barang/Obat, Penerimaan Tagihan

c. Output : Kas, Piutang, Persediaan Obat, Rasio Lancar diperoleh dari aktiva lancar dibagi dengan kewajiban lancar yang menggambarkan kemampuan rumah sakit didalam memenuhi kewajiban jangka pendeknya yang jatuh tempo, (kas+piutang+persediaan)/ (kewajiban pada vendor+Uang Muka Pasien) (Neumann, 1995) 
- Sumber daya manusia

- Sumber Daya Uang

- Prosedur/Metode

- Mesin/Kompute

Keterangan :
- Penerimaan kas

- Pengeluaran kas

- Pre-admission

- Admission

- Inhouse

- Billing

- Collecting

- Write-off

- Penerimaan Kebutuhan

- Pemesanan Obat

- Penerimaan Barang

- Penerimaan Tagihan

- Pencatatan Persediaan

$$
=\text { Area Penelitian }
$$

\section{b. Definisi Operasional}

\section{Proses}

- Penerimaan kas adalah setiap transaksi yang diterima dari hasil penjualan jasa pelyanan mau pun dari sumber lainnya. Sumber data: analisis secara mendalam laporan keuangan serta wawancara mendalam kepada pihak terkait dengan penerimaan kas yaitu Kasir dan melakukan pengamatan proses penerimaan kas di lapangan

- Pengeluaran kas adalah : setiap transaksi yang dikeluarkan untuk membayar biaya- biaya baik itu pengeluaran operasional, pengeluaran pembiayaan, dan pengeluaran pengembangan yang menyebabkan berkurangnya saldo kas. Sumber data : analisis secara mendalam laporan keuangan serta wawancara mendalam kepada pihak terkait dengan pengekuaran kas yaitu Kepala urusan perbendaharaan dan melakukan pengamatan proses pengeluaran kas di lapangan 
- Pre Admission/Pra penerimaan adalah tahap awal untuk mendapatkan informasi yang diperlukan oleh RS dari pasien/penanggungjawab sebelum pasien mendapat layanan kesehatan. Sumber data : wawancara mendalam kepada pihak terkait dengan pra penerimaan yaitu Bagian Loket Pendaftaran, dan atasannya yaitu Kepala Bagian Informatika.

- Admission/ Penerimaan adalah tahap penerimaan pasien di RS untuk mendapatkan layanan kesehatan. Sumber data : wawancara mendalam kepada pihak terkait dengan pra penerimaan yaitu Bagian Loket Pendaftaran, dan atasannya yaitu Kepala Bagian Informatika.

- Tahap Perawatan/inhouse adalah proses pembebanan biaya atas pelayanan yang diberikan oleh RS baik pelayanan medis mau pun penunjang medis. Sumber data : wawancara mendalam kepada pihak terkait dengan pencatatan rincian biaya pasien yaitu Penata Rekening, bagian Piutang Pasien dan melakukan pengamatan di lapangan.

- Billing/Penataan rekening adalah proses penataan rekening tagihan dari pasien yang menerima pelayanan kesehatan. Sumber data : wawancara mendalam kepada pihak terkait dengan pencatatan rincian biaya pasien yaitu Staf Penata Rekening, bagian Piutang Pasien dan laporan keuangan yang dihasilkan dan melakukan pengamatan proses penataan rekening di lapangan.

- Collecting/Penagihan adalah penagihan yang dilakukan oleh urusan penagihan atas jasa pelayanan yang telah diberikan oleh RS yang belum dibayar oleh pasien/Penangggung jawab pasien baik selama atau sesuadah lepas dirawat. Sumber data : analisis secara mendalam laporan keuangan serta wawancara mendalam kepada pihak terkait dengan penagihan piutang yaitu Penata rekening, Bagian Piutang dan Bagian Penagihan/collecting dan melakukan pengamatan proses penagihan piutang di lapangan.

- penutupan rekening/write-off adalah rekening pasien ditutup dan dihapusbukukan dari catatan piutang bila pasien sudah melunaskan atau kebijakan pimpinan RS menghapus piutang tsb dengan alasan umur piutang yang sudah tua. Sumber data : analisis secara mendalam laporan keuangan serta wawancara mendalam kepada pihak terkait dengan penutupan rekening yaitu Kepala Bagian Keuangan dan Bagian 
Penagihan/collecting dan melakukan pengamatan proses penututpan rekening piutang di lapangan.

- Permintaan kebutuhan adalah rekapitulasi kebutuhan dari masing-masing unit RS dalam rangka menjalankan operasional layanan kesehatan sehari-hari. Sumber data : analisis secara mendalam laporan keuangan serta wawancara mendalam kepada pihak terkait dengan Permintaan kebutuhan yaitu Kepala Bagian Keuangan dan kepala Departemen Farmasi, Bagian Anggaran dan melakukan pengamatan proses penututpan rekening piutang di lapangan

\section{Out Put}

Rasio lancar adalah rasio yang menggambarkan kemampuan rumah sakit didalam memenuhi kewajiban lancarnya yang jatuh tempo dengan menggunakan harta lancarnya, Sumber data : analisis secara mendalam laporan keuangan serta wawancara mendalam kepada pihak terkait yaitu Direktur RS, Kepala Bagian Keuangan Wadir Adiministrasi dan Keuangan.

\section{Rancangan Penelitian}

Menggunakan rancangan penelitian operasional yaitu penelitian yang menggunaan data kuantitatif dan data kualitatif untuk mendapatkan jawaban atas pertanyaan penelitin. Data kualitatif diperoleh melalui wawancara mendalam (Sanapiah, 1990). Data kuantitatif diperoleh melalui data keuangan rumah sakit beserta dokumen pendukungnya dianalisisi.

\section{Lokasi dan waktu penelitian}

Di RS X untuk laporan keuangan tahun 2000, 2001, dan 2002, khususnya untuk transaksi Aset lancar dan kewajiban lancar

\section{Informan Penelitian}

Menggunakan teknik sampling metode tak acak (Non Probabilty Sampling) yaitu judgment Sampling/Purposive Sampling. Informan penelitian Direktur RS, Wadir Adm \& Keu, KabagKeu beserta stafnya terkait transaksi Aset lancar dan kewajiban lancar.

\section{Pengumpulan Data}

Mengumpulkan data primer melalui pengamatan langsung dan data sekunder dipeoleh melalui laporan keuaangan dan perincian data keuangan beserta dokumen-dokumen pedukungnya.

4. Pengolahan Data :

- editingadalah data yang terkumpul melalui proses editing untuk mengetahui kualitas data atau informasi yang 
diperoleh, apakah sudah sesua dan memadai.

- Pengelompokan data, dimana data yang diperoleh dikelompokan sesuai kriteria yang sesuai atau sejenis untuk mempermudah peringkasan

- Ringkasan Data, dimana setelah mengatur data, langkah selanjutnya adalah meringkas data menurut kelompok atau kriteria yang sama.

- Analisis Data, dilakukan analisis data sesuai topik/makalh untuk menjawab tujuan penelitian yang berasal dari kuesioner saat wawancara mendalam. Juga dilakukan perbandingan antara temuan atau informasi yang diperoleh dengan tunjauan pustaka atau litertur yang relevan

- Penyajian Data, atas data yang sudah diringkas dalam bentuk narasi yang sesuai berdasarkan temuan dan ringkasan peneliti dari para informan.

\section{Proses Penelitian}

Pengumpulan data primer dan sekunder dilaksanakan di RS X dari bulan Maret sampai dengan Juni 2003. Data Primer diperoleh melalui wawancara mendalam dengan para informan yang terpilih, sedangkan data sekunder diperoleh melalui observasi dan pengumpulan dokumen-dokumen dan laporanaporanyang berhubungan dengan Bagian Keuangan dan Bagian Farmasi menyangkut persediaan obat. Laporan dan dokumen tersebut berupa laporan keuangan, buku besar penerimaan kas, buku besar pengeluaran kas, buku besar piutang, daftar piutang, buku besar persediaan, laporan stock opname persediaan obat per 31 Desember 2002. Observasi lapangan untuk Proses dan Standar Operasional Prosedur untuk pencatatan persediaan obat-obatan, penilaian dan pengawasan persediaan obat-obatan, prosedur pencatatan kas baik di bank mau pun penerimaan kas lainnya, prosedur pengeluaran kas bank dan kas RS, prosedur perencanaan penerimaan kas dan pengeluaran kas (Anggaran Kas). Untuk kebijakan dan pendalaman materi yang diteliti penulis melakukan wawancara mendalam dengan Direktur sebagai pembuat kebijakan garis besar untuk keseluruhan RS, Wadir Adm \& Keu sebagai tangan kanan yang akan menerjemahkan kebijakan yang telah diputuskan oleh Direktur, Kabag Keu sebagai manajer yang mengepalai Urusan Keuangan dan Akuntansi, Kabag Instalasi Farmasi sebagai Manajer Persediaan 
Obat-obatan, Pelaksana di Bagian Keuangan dan Farmasi yaitu: Ka. Ur. Akuntansi, Ka. Ur. Piutang, Ka. Ur. Perbendaharaan, Ka. Ur. Anggaran, Koordinator Uang Muka Pasien Rawat Inap. Selanjutnya dilakukan kajian yang mendalam atas hasil wawancara dengan informan-informan diatas.

\section{Keterbatasan Penelitian}

Keterbatasan penelitian ini adalah adanya perbedaan waktu antara keadaan operasional/proses sekarang dan pada saar rasio lancar itu dihasilkan tahun 2000, 2001, 2002, sedang data dikumpulkan sejak Maret sampai dengan Juni 2003. Adanya data yang bersifat confidential yaitu sisi modal dari Neraca dan Biaya Administrasi dan Umum juga membuat pembahasan hasil penelitian memiliki keterbatasan pula.

Keterbatasan lainnya dalam penelitian ini adalah tidak dilakukannya Focus Group Discussion (FGD) disebabkan karena sulitnya untuk mengumpulkan pihak-pihak yang terkait secara bersamaan karena memiliki kesibukan masing-masing dan tidak bisa meninggalkan pekerjaannya. Sehingga teknik penelitian riset operasional dengan mengumpulkan data kuantitatif berupa laporan keuangan dan data kualitatif yang dilakukan dengan wawancara mendalam dan observasi partisipatif. Dengan tidak dilakukan FGD maka dalam penelitian ini tidak dapat diperoleh umpan balik dari setiap bagian/unit atas unit/bagian yang lain untuk menjawab pertanyaan penelitian. Dengan wawancara mendalam alur pembicaraan hanya satu arah dengan FGD diperoleh informasi dari pembicaraan timbal balik. Tapi walau pun hanya dengan wawancara mendalam, cross check data tetap dilakukan untuk menjamin validitas.

Penelitian ini memfokuskan kepada analisis rasio lancar yang memprioritaskan pada proses dan output dari perkiraan-perkiraan harta lancar. Penelitian ini menyangkut perkiraan yang mempunyai porsi terbesar/significant yaitu mencakup proses penagihan piutang rawat inap, proses terjadinya saldo kas, proses persediaan obat farmasi (porsi terbesar untuk perkiraan persediaan). Rasio lancar diperoleh dari data sekunder RS tanpa melihat kembali tingkat accuracy dari laporan keuangan tersebut, tetapi laporan keuangan RS X senantiasa di audit oleh pihak independen yaitu Kantor Akuntan Publik dengan opini Wajar Tanpa Pengecualian yang artinya laporan keuangan bebas dari salah saji yang material. Penelitian ini dilakukan fokus pada proses dimana yang dilihat mencakup aspek perencanaan, 
pelaksanaan, pengawasan dan koordinasi. Kemudian dari sisi output dianalisis rasio lancar untuk tiga tahun yaitu 2000, 2001 dan 2002.

\section{ANALISIS DAN PEMBAHASAN}

\section{Kas, Bank, Deposito}

\section{a. Penerimaan Kas}

Pelaksanaandilapangan proses pembayaran tunai di RS X diterima di kasir terpisah yaitu kasir Apotik, kasir UGD, kasir Poliklinik/Rawat Jalan dan Kasir Sentral (Kasir Rawat Inap). Ketiga kasir akan memberikan laporan memorial kas ke kasir sentral dengan urut nomer sebagai kontrol penerimaan dan pencatatan kas. Kasir Apotik merupakan staf bagian keuangan bekerja dengan 3 shift supaya pasien dapat telayni 24 jam perhari. Kasir sentral hanya 2 shift, setelah itu penerimaan kas diserahkan ke kasir apotik/rawat jalan yang bekerja 3 shift.
Kontrol Penerimaan kas dilakukan oleh Kabag Keuangan sesuai sumber penerimaan kas tersebut, dimana penerimaan dari Piutang Pasien dilakukan cross check ke daftar piutang dengan cheque yang masuk ke bank, sedangkan untuk pasien rawat jalan belum dilakukan cross check dengna jumlah pasien dibagian pendaftaran/admission, untuk uang muka pasien rawat inap juga belum di dilakukan cross check dengan jumlah pasien.

\section{b. Pengeluaran Kas}

Pengeluaran kepada pihak ketiga dibuat dengan membuat rekapitulasi bukti penerimaan barang yang discocokkan dengan faktur dari pihak ketiga lalu diminta persetujuan ke Kabag Keu baru dilakukan pembayaran, sedangkan untuk transaksi pengeluaran rutin dikeluarkan langsung oleh Kabag Keu melalui Ka Ur Perbendaharaan dan untuk pengeluaran non rutin harus melalui persetujuan Direktur/ Pimpinan RS 
Tabel 1.2

Analisis vertikal Kas, Piutang dan Persediaan per tanggal 31 Desember 2000, 2001 dan 2002

\begin{tabular}{|c|c|c|c|c|c|c|}
\hline Akun & 2002 (rupiah) & $\%$ & 2001 (rupiah) & $\%$ & 2000 (rupiah) & $\%$ \\
\hline \multicolumn{7}{|l|}{ ASET LANCAR } \\
\hline Kas, Bank, desposito & 483.179 .921 & 22 & 624.296 .522 & 30 & 929.122 .882 & $40 \%$ \\
\hline Piutang Instansi & 792.780 .581 & 35 & 665.641 .118 & 32 & 519.083 .140 & 22 \\
\hline Piutang perorangan & 352.798 .640 & 16 & 310.200 .945 & 15 & 269.831 .345 & 12 \\
\hline $\begin{array}{l}\text { Cadangan Penghapusan } \\
\text { Piutang }\end{array}$ & $(85.515 .750)$ & (4) & $(73.382 .2700)$ & 3 & $(90.605 .675)$ & 4 \\
\hline Piutang karyawan & 92.791 .755 & 4 & 97.650 .581 & 5 & 116.239 .781 & 5 \\
\hline Persediaan & 590.861 .745 & 26 & 451.779 .712 & 21 & 558.951 .922 & 24 \\
\hline Biaya dibayar dimuka & 6.804 .000 & 0.30 & 34.053 .333 & 2 & 23.155 .000 & 1 \\
\hline Total Aset lancar & 2.233 .700 .892 & 100 & 2.110 .239 .941 & 100 & 2.325 .778 .395 & 100 \\
\hline \multicolumn{7}{|l|}{ KEWAJIBAN LANCAR } \\
\hline Utang Supplier & 642.522 .972 & 60 & 850.642 .677 & 58 & 644.218 .309 & 64 \\
\hline Biaya YMH dibayar & 325.182 .853 & 30 & 506.889 .282 & 34 & 38.860 .200 & 4 \\
\hline Utang UM Pasien & 64.277 .150 & 6 & 69.792 .900 & 5 & 45.210 .946 & 5 \\
\hline Utang Pajak & 45.757 .808 & 4 & 48.692 .535 & 3 & 273.731 .669 & 27 \\
\hline Total Kewajiban Lancar & 1.077 .740 .783 & 100 & 1.476 .017 .394 & 100 & 1.002 .021 .124 & 100 \\
\hline MODAL KERJA & 1.155 .960 .109 & & 634.222 .547 & & 1.323 .757 .271 & \\
\hline
\end{tabular}

Sumber : Laporan Keuangan RS X, diolah kembali oleh penulis

Akun kas, bank dan deposito selama tiga tahun terakhir yaitu 2000, 2001 dan 2002 secara prosentase terus menurun yaitu $40 \%$, lalu $30 \%$ terakhir tahun 2002 hanya 22\% ( Tabel 1.3) dan jika dilihat kecenderungannya (trend) selama tiga tahun terakhir ini memang mengalami penurunan terus menerus yaitu sebesar $22 \%$ untuk tahun
2000, turun sebesar 33\% pada tahun 2001 dan turun sebesar 23\% pada tahun 20X2 (Tabel 1.3). Hal ini terjadi karena RS X melakukan pencairan dana deposito untuk keperluan renovasi Poliklinik/Unit Rawat Jalan, adanya proses pembuatan business plan.

Tabel 1.3

Analisis horizontal Pendapatan Bersih Layanan RS X untuk tahun berakhir pada tanggal 31 Desember 2000, 2001 dan 2002

\begin{tabular}{|c|c|c|c|c|c|c|}
\hline Jenis Pelayanan & $\begin{array}{c}\text { Naik/ } \\
\text { (turun) }\end{array}$ & $\begin{array}{c}2002 \\
\text { Pendapatan- } \\
\text { HPP }\end{array}$ & $\begin{array}{c}\text { Naik/ } \\
\text { (turun) }\end{array}$ & $\begin{array}{c}2001 \\
\text { Pendapatan - } \\
\text { HPP }\end{array}$ & $\begin{array}{c}\text { Naik/ } \\
\text { (Turun) }\end{array}$ & $\begin{array}{c}2000 \\
\text { Pendapatan- } \\
\text { HPP }\end{array}$ \\
\hline Rawat Jalan & 35 & 435.566 .723 & $(194)$ & 323.345 .343 & $(220)$ & $(345.243 .424)$ \\
\hline UGD & 7 & $(194.311 .405)$ & $(134)$ & $(181.668 .902)$ & 7773 & 533.684 .300 \\
\hline
\end{tabular}




\begin{tabular}{|c|c|c|c|c|c|c|}
\hline Jenis Pelayanan & $\begin{array}{c}\text { Naik/ } \\
\text { turun) }\end{array}$ & $\begin{array}{c}2002 \\
\text { Pendapatan- } \\
\text { HPP }\end{array}$ & $\begin{array}{c}\text { Naik/ } \\
\text { (turun) }\end{array}$ & $\begin{array}{c}2001 \\
\text { Pendapatan - } \\
\text { HPP }\end{array}$ & $\begin{array}{c}\text { Naik/ } \\
\text { (Turun) }\end{array}$ & $\begin{array}{c}2000 \\
\text { Pendapatan- } \\
\text { HPP }\end{array}$ \\
\hline Rawat Inap Umum & $(4)$ & 1.111 .723 .818 & 28 & 1.159 .926 .558 & 81 & 909.185 .171 \\
\hline Rawat Inap Anak & 34 & $(150.773 .351)$ & $(210)$ & $(112.717 .558)$ & 32 & 102.392 .279 \\
\hline $\begin{array}{c}\text { Rawat Inap } \\
\text { kebidanan }\end{array}$ & 5 & 312.761 .143 & $(42)$ & 297.660 .418 & 62 & 516.167 .005 \\
\hline Farmasi & 10 & 1.650 .519 .949 & 19 & 1.506 .681 .235 & 36 & 1.263 .474 .748 \\
\hline Laboratorium & 29 & 786.262 .451 & 5 & 611.174 .340 & 52 & 579.882 .716 \\
\hline Radiologi & 47 & 322.211 .072 & 3 & 219.239 .944 & 30 & 212.227 .949 \\
\hline Kamar Bedah & 20 & 912.720 .093 & 49 & 761.398 .261 & 33 & 512.045 .824 \\
\hline Utilitas Lain & $(2)$ & 1.215 .699 .795 & $(5)$ & 1.246 .688 .005 & $(414)$ & 1.308 .012 .180 \\
\hline TOTAL & $\mathbf{1 0}$ & $\mathbf{6 . 4 0 2 . 3 8 0 . 2 8 8}$ & $\mathbf{4}$ & $\mathbf{5 . 8 3 1 . 7 2 7 . 6 4 4}$ & $\mathbf{1 1 3}$ & $\mathbf{5 . 5 9 1 . 8 2 8 . 7 4 8}$ \\
\hline
\end{tabular}

Berdasarkan analisis horizontal, diperoleh informasi bahwa pendapatan bersih RS X naik pada tahun 2000 (113\%), pada tahun 2001 mengalami peningkatan yang sangat kecil (4\%) dan pada tahun 2002 kenaikannya hanya 10\% ( Tabel 1.3). Jika dicermati dari kinerja layanan (Tabel 1.1) terjadi penurunan BOR RS X untuk tiga tahun terakhir dan berdasarkan wawancara dengan Kepala Bagian keuangan, selama ini terus dilakukan penyesuaian tarif dan belum kearah peningkatan efisiensi didalam mengantisipasi kenaikan pengeluaran operasional RS.

Jika dilihat dari analisis vertikal pada komponen pendapatan kotor untuk tahun 2000, 2001 dan 2002 terlihat bahwa unit produksi yang masuk dalam tiga besar adalah Farmasi, Unit Rawat Inap Umum, dan Kamar bedah. Tetapi jika dilihat dari komponen pendapatan bersih, unit produksi yang masuk dalam tiga besar adalah Farmasi, Rawat Inap Umum dan Utilitas lainnya kecenderungan dari pendapatan bersih yang berfluktuasi ini tentu akan berdampak pada jumlah penerimaan kas RS X yang akan berdampak pada likuiditas dan rasio lancar RS

Anggaran yang dibuat haruslah sejalan dengan visi dan misi RS yang tertuang di Renstra dan dijabarkan di Business Plan, anggaran bisa dijadikan sebagai suatu komitmen untuk efisiensi sesuai dengan target yang telah tercantum dianggaran tersebut. Uang kas berarti komitmen setiap anggota RS untuk mencapai suatu saldo yang diperoleh dari selisih penerimaan kas yang diperoleh dari pasien dan pengeluaran yang dilakukan dalam rangka mendapatkan penerimaan tersebut. Disebut memberikan dampak bagus 
untuk arus kas jika penerimaan kita terima diatas pengeluaran yang dilakukan.

Di RS X, sumber penerimaan kas dari unit produksinya yaitu rawat jalan, rawat inap, dan unit penunjang seperti laboratorium, farmasi, radiologi dan lain-lain, dimana masing-masing unti produksi menetapkan target jumlah pasien yang akan berkunjung sesuai dengan kemampuan yang ada serta ramalan permintaan yang akan terjadi dengan mempertimbangkan juga aspek eksternal yaitu ekonomi penduduk, tren yang sedang berlaku, serta regulasi dan epidemiologi penyakit. Sehingga didalam membuat anggaran kas menurut Bedford (1992), anggaran operasi suatu organisasi merupakan rencana tindakannya, biasanya dinyatakan dalam satuan uang, untuk periode tertentu, biasanya satu tahun. Selanjutnya Bedford mengatakan bahwa, dalam proses penganggaran, anggaran umumnya disusun dengan menggabungkan anggaran-anggaran divisi atau departemen, yang merupakan tanggungjawab manajer divisi/departemen.

Di RS X anggaran kas memang sudah dibuat berdasarkan permintaan masing-masing unit ditambah kemungkinan sekian persen, tetapi sampai saat ini belum ada evaluasi atas realisasi anggaran tersebut untuk masing-masing unitnya. Padahal menurut bedford (1992), suatu sistem pengendalian manajemen ada unsur evaluasi setelah perencanaan dan akan pelaksanaan dari anggaran tersebut. Perlunya diinformasikan ke masing-masing unit akan anggaran/target, sehingga diketahui saldo yang harus dicapai sebagai motivator didalam melaksanakan tugas sehari-hari. Dan sudah saatnya sekarang ditimbulkan self control atas saldo pengeluaran masing-masing unit dengan mengetahui saldo anggaran yang masih tersisa setiap akan mengajukan permintaan ke Bagian Pengadaan.

Untuk Pelaksanaan penerimaan kas yang diterimakan di kasir sentral dari tiga kasir lainnya yaitu kasir rawat jalan/apotik, kasir rawat jalan (dekat admission) dan kasir UGD, perlu ditingkatkan akuntabilitasnya. Menurut Arens (1994), suatu pengendalian dari kas adalah adanya segregation of duties yaitu adanya pemisahan antara pihak yang melakukan fungsi penerimaan, pencatatan dan penyimpanan dari fisik kas tersebut. Sehingga akuntabilitas dari saldo kas dapat dipertanggungjawabkan dan tertib administrasi kas dapat dijalankan.

Perencanaan dan pengendalian dari kas mempunyai tujuan sebagai berikut:

1. Perencanaan yang tepat, sehingga dana yang diperoleh dapat digunakan untuk operasional usaha sehari-hari baik untuk jangka panjang mau pun jangka pendek

2. Penggunaan dana yang seefisien mungkin 
3. Menciptakan akuntabilitas penerimaan kas dan disimpan dalam keadaan yang aman sampai kas itu disetor ke bank

\section{Piutang}

Pada saat ini belum ada tim khusus untuk menagih pasien perorangan yang jumlahnya 12$16 \%$ dari harta lancar RS X, selama ini staf penagihan instansi juga merangkap untuk staf penagihan perorangan. Saldo perkiraan piutang perorangan untuk tahun 2002 sebesar Rp 352.798.640,- dengan komposisi 30\% berumur diatas 3 tahun yang artinya sudah tidak lancar lagi. Berdasarkan wawancara dengan Kabag Keu, kemungkinan untuk tertagihnya juga sangat tipis. Sebenarnya RS X sudah melakukan penghapusbukukan Rp 85 juta ( $85 \%)$. Tetapi karena RS X tidak melakukan penyisihan piutang, maka nilai terealisasi dari piutang jauh dibawah saldo yang disajikan dilaporan keuangan, yang angkanya kita gunakan untuk menghitung rasio lancar.

\section{a. Piutang}

Menurut Mehta (1988), RS perlu membuat prosedur kredit kepada pasien untuk mengetahui kemampuan dari pasien didalam membayar tagihan RS, tagihan yang dibuat lengkap, baik dan alternatif prosedur penagihan piutang pasien.

Pintu gerbang masuk pasien yaitu di Admission perlu dibuat aturan yang lebih jelas dan informatif kepada pasien, sehingga menjamin bahwa pasien mendapatkan layanan sesuai dengan kemampuannya. Hal ini berlaku terutama untuk pasien rawat inap perorangan $\mathrm{RS} \mathrm{X}$ didalam pemberian kredit kepada pasien selama ini bersifat agak longgar karena pertimbangan segmen pasar menengah ke bawah dan kurang tegasnya para karyawan terhadap calon pasien/orang sakit. Admission sebagai penjaga gawang depan RS untuk menyaring pasien yang masuk selama ini kurang berjalan, karena ada unsur tidak tega demi kemanusiaan. Sehingga pasien bisa masuk mendapat layanan tanpa ada kejelasan status pasien jaminan tersebut, apakah layanan diperoleh pasien termasuk yang mendapat penggantian dari asuransi/pihak ketiga.

Dilapangan, selama ini untuk pasien rawat inap dengan status sudah boleh pulang oleh dokter dan belum mampu melunasi kewajibannya bisa langsung meninggalkan rumah sakit dengan memberikan jaminan yang kurang kuat untuk menjamin si pasien untuk melunasi hutangnya diwaktu yang akan datang, misalnya KTP, sehingga pasien pun kurang terpacu untuk melunasi piutangnya.

Padahal RS X sudah memiliki SOP (Standar Operasional Prosedur) untuk pasien rawat inap yang kalau dijalankan dilapangan tentu piutang pasien tidak akan bersaldo sebesar saat ini (tahun 2001). 
Menurut Pernyataan Standar Akuntansi Indonesia (PSAK, 2011) untuk Piutang yang berumur diatas satu tahun sebaiknya diklasifikasikan di Neraca (Laporan Posisi Keuangan) sebagai Piutang tidak lancar. Hal ini tentu akan memiliki dampak terhadap angka Rasio Lancar RS X, yang akan semakin kecil karena aset lancar (piutang) menjadi lebih kecil lagi karena formula rasio lancar adalah aset lancar dibagi dengan kewajiban lancar.

Berdasarkan dari wawancara mendalam dengan Kepala Bagian Keuangan RS X diperoleh informasi bahwa $70-80 \%$ Piutang tak tertagih memang berasal dari pasien tanpa jaminan/pasien bayar sendiri dan umur piutangnya juga diatas 90 hari dan bahkan ada yang diatas 360 hari. Sayangnya jumlah pendapatan RS dari pasien tanpa jaminan ini tidak dapat diperoleh datanya sehingga tidak diketahui proporsi tagihan pasien perorangan yang tidak tertagih. Selama ini RS X belum melakukan manajemen piutang perorangan yang efektif, sehingga piutang itu sebenarnya sudah tidak dimunculkan lagi di Neraca, ini menyebabkan saldo piutang di Neraca RS X menjadi lebih catat/over stated. Sehingga artinya angka rasio lancar RS X tahun 2001 jauh lebih kecil lagi dari angka yang ada sekarang.

Berdasarkan telaah saldo Piutang yang dimunculkan di Neraca RS X pada 31 Desember 2002 adalah sebagai berikut :

Tabel 1.4

Umur Piutang RS X tahun 2002

\begin{tabular}{|l|l|c|c|c|c|c|}
\hline No. & Klasifikasi Piutang & 0-30 hari & $31-60$ hari & $61-120$ hari & $>120$ hari & Jumlah \\
\hline 1 & Piutang Instansi & $275.001 .450,-$ & $176.075 .400,-$ & $70.524 .000,-$ & 197.578 .881 & 719.179 .731 \\
\hline 2 & Piutang PT Askes & & $73.540 .850^{*}$ & & & 73.540 .850 \\
\hline 3 & $\begin{array}{l}\text { Piutang } \\
\text { Perorangan }\end{array}$ & 323.194 .560 & 23.312 .550 & 4.550 .945 & 301.740 .585 & \\
\hline & Jumlah & 296.196 .010 & 272.928 .810 & 75.074 .945 & 499.319 .466 & 1.143 .519 .231 \\
\hline
\end{tabular}

Sumber : Keuangan RS X, diolah kembali

* berdasarkan estimasi direktur keuangan

Pada tabel diatas terlihat bahwa Piutang Instansi mempunyai umur yang cukup tua sebesar Rp 197.578.881 yang artinya, tingkat kemungkinan untuk tertagihnya (penerimaan kas) adalah sangat kecil sekali, sedangkan pencatatan akuntansi di Indonesia menganut konservatism (PSAK, 2012), yang artinya kalau memang kemungkinan tertagihnya sangat kecil dan jika setelah ditelusuri keberadaan bisnis dari instansi itu juga sedang bermasalah, maka bisa dipastikan 
saldo akun piutang yang disajikan juga lebih catat/overstated. Perlu dilakukan telaah lebih lanjut atas catatan historis dari si pemberi jaminan jika kelak akan membuat kontrak dengan pihak ketiga untuk mencegah terjadinya ketidakmampuan bayar dari perusahaan penjamin.

Untuk saldo akun piutang Askes sebesar Rp 73.540.850 (7\% dari total piutang), RS X tidak mempunyai dokumen pendukung atas umur piutang ini, sehingga tidak diketahui juga apakah bisa tertagih atau tidak, jangan sampai likuiditas RS X merupakan likuiditas yang tidak sebenarnya/semu.

Pada saldo Akun Piutang Peorangan didominasi oleh piutang berumur diatas 120 hari (85\%), yang artinya tingkat konversi untuk menjadi kas/penerimaan kas menjadi sangat keci juga, apalagi ini pasien perorangan dimana alamatnya sudah tidak sama lagi dengan yang tercantum didata RS. Pada saat dihitung cost benefit untuk mengaih juga tidak seimbang. Dimasa yang akan datang perlu disiplin dari semua pihak terkait untuk menjalankan prosedur penerimaan pasien perorangan, jaminannya perlu dibuat signifikan dari pada hanya sekadar KTP dan BPKB kendaraan. Perlu komitmen tinggi mulai dari admission, perawat mau pun bagian keuangan untuk menjalankan prosedur pemberian sanksi/evaluasi atas penundaan pasien untuk setiap penundaan menyetorkan uang muka/deposit atau cicilan selama pasien sudah masuk ruang rawat inap. Pada $\mathrm{RS} \mathrm{X}$ juga terjadi keterbatasan atas Sumber Daya Manusia yang melakukan penagihan dari Bagian Keuangan.

\section{b. Persediaan}

Berdasarkan pengamatan dilapangan diperoleh Alur Permintaan Barang, dimana terlihat bahwa Apotek/Depo setiap hari kerja membuat Daftar Permintaan Barang yang diikuti dengan Laporan Pemakaian obat Ruangan (Bukti Pemakaian Obat Ruangan), lalu diajukakan ke gudang farmasi dalamrangka untuk penyediaan barang, lalu barangobat dikeluarkan, catat dikartu persediaan setiap transaksi terjadi.

Untuk mengetahui jumlah persediaan obat yang ada baik di Depo, Apotik mau pun ruangan baik UGD, Rajal mau pun Ranap dilakukan stock opname setiap bulan. Belum ada kartu persediaan dimasing-masing tempat tersebut untuk mengetahui mutasi persediaan antara saldo awal dengan saldo persediaan tersisa. Sedangkan untuk mengetaui nilai persediaan obat yang tercantum di Laporan Keuangan diperoleh dengan LIFO (Last In First Out), dimana dipakai harga terakhir untuk item obat yang sama.

\section{Fluktuasi kas, Piutang dan Persediaan Obat.}

Modal kerja secara kecenderungan terlihat menurun tajam pada tahun 2001 lebih dari 
setengah modal kerja yang dimiliki tahun sebelumnya (tahun 2000), tetapi pada tahun 2002 naik hampir setengah modal kerja tahun 2001.

Berdasarkan analisis vertikal atas aset lancar per 31 Desember 2000, 2001 dan 2002 diperoleh informasi bahwa, disatu sisi perkiraan kas, bank dan deposito porsinya terus menurun. Sementara dipihak lain piutang instansi dan piutang perorangan porsinya terus meningkat, sedangkan porsi cadangan piutang cenderung tetap.

\section{c. Persediaan Obat-Obatan}

Menurut Soerjandari (1994), berdasarkan penelitian, peningkatan biaya adalah signifikan dengan tidak adanya pengendalian atau kontrol pada persediaan, sehingga mekanisme kontrol yang efektif tidak saja untuk mencapai kedua tujuan tersebut, tetapi juga memecahkan konflik yang terjadi. Salah satu cara yang paling sederhana didalam mengontrol persediaan obat adalah dengan membuat kartu persediaan disetiap pos-pos yang menyimpan persediaan obat, yaitu di Depo Farmasi, Gudang, UGD, Ruangan baik Rawat Jalan mau pun Rawat Inap. Kesiapan SOP dan SDM mutlak diperlukan untuk menjamin tercatatnya setiap mutasi dikartu persediaan dengan benar, akurat, cepat dan valid. Jika dana memungkinkan bisa membuat sistem kontrol persediaan disetiap pos persediaan obat yang terkomputerisasi dan terintegrasi sehingga saldo akun persediaan obat bisa diketahui setiap saat.
Untuk obat yang dipakai diruangan, selama ini merupakan data yang dibuat oleh perawat ruangan, tanpa ada paraf pada kartu persediaan, yang sebenarnya dari sisi keuangan diperlukan untuk masalah validitas pemakaian obat itu sendiri, sedangkan dari sisi medis akan melindungi RS dan dokter jika dikemudian hari ada masalah hukum dengan pasien.

Perencanaan persediaan obat haruslah menjamin bahwa persediaan obat yang ada di rumah sakit berada pada level yang minimal, karena adanya biaya penyimpanan persediaan obat yang sangat tinggi belum lagi kalau slow moving, dikhawatirkan obat belum dipakai tetapi sudah kadaluarsa, jika ini terjadi merupakan tindakan yang sangat merugikan rumah sakit dari segi arus kas.

Menurut Yenis (1998), didalam pemesanan obat haruslah dicek lagi apakah obat yang diterima sudah sesuai dengan item dan jumlah obat yang diminta pleh unit-unit yang terkait baik dari ruangan (rawat inap), apotik mau pun UGD. Selama ini pengecekan obat yang diterima hanyalah ke surat pesanan yang ditujukan kepada distributor, bukan dicocokkan dengan surat permintaan dari unit-unit. Padahal dasar pemesanan adalah surat permintaan unit ini, karena merekalah pihak yang berkepentingan.

$$
\text { Begitu juga didalam pemilihan }
$$
rekanan/distributor/Pedagang Besar farmasi 
(PBF) untuk mendapatkan harga yang bersaing sebaiknya melalui mekanisme tender dan bukan penunjukkan langsung. Minimal RS X mempunyai prosedur pemilihan PBF yang menguntungkan baik dari segi kualitas dan kuantitas barang, juga yang memberikan fasilitas dispensasi waktu bayar yang cukup panjang untuk menghindari RS terkena sanksi pinalti atas keterlambatan bayar dan tentu saja dengan harga yang bersaing.

Ada beberapa kondisi yang penting didalam pengelolaan persediaan (Heckert, 1990)

1. Definisi yang jelas atas tanggung jawab dan wewenang yang menyangkut persediaan, untuk obat apakah obat itu bisa diapaki oleh karyawan? Obat jenis apa saja? Lalu apakah ada obat yang disimpan dalam kondisi terkunci dan wewenang siapa kunci itu dan sebagainya

2. Definisikan dengan baik tujuan dan kebijakan yang diambil, jika terjadi resep diluar formularium langkah apa saja yang akan diambil, begitu juga dengan adanya obat yang kadaluarsa langkah apa yang akan diambil?

3. Penyimpanan yang memadai dan fasilitas penyimpanan

4. Klasifikasi persediaan yang tepat dan identifikasi yang jelas

5. Standarisasi dan penyederhanaan dari persediaan
6. Pencatatan dan laporan yang memadai, sediakan kartu persediaan disetiap penyimpanan obat, setiap mutasi dilakukan pencatatan yang jelas baik itu untuk jenis item obat dan jumlahnya serta paraf yang mengambil obat dan juga paraf dokter yang menuliskan resepnya. Jika sudah komputerisasi yang terintegrasi lebih baik lagi akuntabilitas dari persediaan obat

7. Pegawai/SDM yangbertanggungjaab dan memuaskan, dimana prosedur yang ada akan diikuti dengan penuh tanggungjawab dan bisa mengatasi setiap masalah yang dihadapi dilapangan.

Pada RS X, selama ini jika memiliki dana yang terbatas yang dibandingkan dengan kebutuhan obat yang diminta, dipakai pertimbangan skala prioritas membeli obat yang fast moving. Menurut yenis (1998), jika rumah sakit pada posisi keterbatasan dana untuk membeli obat, maka masyarakat memakai VEN. Berarti masyarakat melihat apakah obat itu penting sekali tidak didalam menyelenggarakan pelayanan kesehatan sesuai visi misi RS X.

Selama ini RS X mencatat persediaan berdasarkan harga pembelian dari pemasok dan tidak terdapat persediaan yang usang atau kadaluarsa. Akun Persediaan dihitung berdasarkan stock opname yang dilakukan setiap akhir bulan. 
Jika dilihat dari kinerja likuiditas, likuiditas RS X selama ini hanya dipergunakan untuk membiayai keperluan operasional seperti jasa medis, membeli obat-obatan dan pengeluaran rutin lainnya. RS X belum berani melakukan pengembangan, padahal alokasi penerimaan kas sebaiknya digunakan secara seimbang antara pengeluaran operasional, investasi dan pembiayaan, baik yang bersifat lancar dan tidak lancar.

Pada saat berdiri, sekitar tahun 1980- an RS $\mathrm{X}$ merupakan market leader didaerahnya, tetapi karena kurang berani melakukan pengembangan, saat ini sudah terlindas oleh beberapa rumash sakit baru yang merupakan rumah sakit yang dikelola lebih berani melakukan pengembangan diberbagai, baik dari sisi alat-alat kesehatan, bangunan rumah sakit yang representatif, dan jenis layanan yang inovatif, yang berdampak posisi RS $\mathrm{X}$ saat ini hanyalah follower. Namun RS X saat secara pelanpelan sudah mulai berbenah diri, berani melakukan pengembangan walau pun terbatas karena memang budaya pemilik RS X yang terlalu sangat hati-hati, yang sudah terlihat dampak pada likuiditas RS X yang agak bermaslaah sedikit, ditandai dengan angka rasio lancar yang turun pada tahun 2001.

Penurunan Rasio lancar pada tahun 2001 terpuruk menjadi 1.42 yang artinya aset lancar yang dimiliki untuk membayar kewajiban lancar hanya berlebih $42 \%$. Walau pun volume produksi meningkat dibandingkan tahun sebelumnya, tetapi ternyata kewajiban kepada vendor sangat besar juga, hal ini karena memang belum jatuh tempo.

Sedangkan pada tahun 2002, walau pun rasio lancar sekitar 2, yang artinya ada kelebihan 100\% dari aset lancar yang digunakan untuk membiayai kewajiban lancar, tetapi kondisi aktivitas pelayanan menurun, BOR menurun, begitu juga dengan utilisasi kapasitas pelayanan kesehatan RS X. Setelah ditelaah lebih lanjut, Rasio lancar yang meningkat semata-mata karena aktivitas pembelian obat yang menurun, sehingga berdampak rasio lancar meningkat. Ditambah piutang perorangan yang berkurang karena bergesernya pasien bayar sendiri yang tidak mampu menjadi pasien yang dibiayai oleh Pemerintah/Gakin.

Secara keseluruhan angka rasio likuiditas RS $\mathrm{X}$ selama 10 tahun terakhir adalah menurun, walau pun terjadi sedikit kenaikan untuk rasio likuiditas tahun 2002, juga rasio lancarnya, tapi kenaikan ini adalah semu. Hal ini terjadi karena sejak tanggal 17 Oktober 2001, berdasarkan surat no. KS.00.1156 yang diterbitkan oleh Departemen kesehatan, menunjuk RS X sebagai salah satu rumah sakit di Kota X untuk melaksanakan Program PD PSE BK KS yang selanjutnya berubah menjadi PKPS-BBM BIDKES (Program Kompensasi Pengurangan Subsidi Bahan Bakar 
Minyak yang Bidang Kesehatan) dalam upaya membantu keluarga miskin untuk memperoleh hak atas akses kesehatan dan kesejahteraan.

Melalui Program PKPS BBM BIDKES RS X mendapatkan alokasi dana sebesar Rp 399.950.000,- untuk tahap I pada bulan November 2001 dan tahap II Rp 399.950.000,- diterima RS X pada bulan Agustus 2002. Dana ini semua digunakan untuk membiayai pelayanan kesehatan GAKIN I wilayah Kota X yang dirujuk melalui Puskesmas setempat dan diketahui oleh RT/RW dimana pasien berdomisili.

Walau pun keuangan Gakin dikelola terpisah dari penngelolaan keuangan RS X, tetapi dampak dari adanya dana ini jelas ada untuk arus kas masuk RS X. Segmen pasar RS X adalah masyarakat menengah kebawah (Suwardjoko, 1999), dimana sebelum adanya dana Gakin ini, pasien tidak mampu yang tidak membayar tagihan RS X akan ditanggung oleh keuangan RS X karena memang RS X secara rutin mendapat donasi dari Pemerintahan Kota (Pemkot) X yang sistemnya tetap, bukan berdasarkan jumlah pasien tidak mampu membayar datang ke RS X. Sehingga pada kenyataannya donasi Pemkot $\mathrm{X}$ tidak menutupi tagihan pasien tidak mampu tsb. Sehingga sebagian besar biaya pasien tidak mampu itu ditanggung oleh RS X. Maka sejak adanya dana Gakin, pasien tidak mampu membayar akan dialihkan oleh pihak rumah sakit, dalam hal ini front office/admission/resepsionis ke pasien Keluarga Miskin (Gakin). Ini sangat membantu keuangan RS X dalam jangka pendek, tetapi tidak untuk jangka panjang karena akan didirikannya RSUD Kota X.

Kepala bagian Keuangan berdasarkan wawancara mendalam mengatakan bahwa, apakah dengan terpilihnya R X sebagai RS penerima dana Gakin akan berdampak positif bagi RS X atau tidak. Karena dikwawatirkan image/citra RS X akanmenjadi kurang bagus didalam menangkap pasien di segmen menengah. Dan untuk jangka panjang ditakutkan dana Gakin tidak diperoleh lagi karena akan berdiri RSUD, tetapi pasien miskin sudah terlanjur menuju RS X. Jika kita melihat angka rasio lancar tahun 2002 menjadi overstated karena adanya pemasukan kas RS X yang merupakan sisi sumbangan/donasi dan bukan dari pendapatan pelayanan RS X. Perlu disini dilakukan penelitian lebih lanjut berapa sebenarnya angka rasio lancar RS X jika tidak memperoleh sumbangan/dana Gakin. Apakah masih bisa bertahan RS X jika RSUD kelak benerbenar berdiri di Kota X?

Rasio lancar angkanya diperoleh melalui perbandingan antara aset lancar dan kewajiban lancar (Neumannm 1995), untuk RS X secara nominal memang masih dibawah batas aman untuk tahun 2002 yaitu $1.5-2.00$ (Sjaaf, 2000), 
tetapi nilai riil dari rasio tersebut sebenarnya jauh dibawah itu, hal ini karena:

a. Piutang jaminan overstated

Yang dinilai terlalu tinggi, dan ada yang berumur diatas 3 tahun masih tercantum di Neraca sebagai aset lancar padahal menurut PSAK (2002). Aset lancar merupakan aset yang bisa dikonversikan menjadi tunai atau ekuivalennya dalam jangka waktu kurang dari satu tahun buku, yang artinya aset lancar RS X over stated

b. Piutang Perorangan yang overstated

Untuk piutang perorangan ini ternyata sebesar $85 \%$ dari total saldo berumur diatas 3 bulan, yang artinya tingkat ketertagihannya adalah sangat kecil, apalagi piutang perorangan ini tidak dijamin dengan barang yang senilai dengan nilai dari piutang itu sendiri, sehingga sangat sukar untuk dikonversikan sebagai kas. Artinya angka rasio lancar adalah overstated.

Hal ini memberikan implikasi bahwa RS $\mathrm{X}$ harus lebih berhati-hati didalam mengelola keuangannya supaya terus bisa eksis sebagai rumah sakit yang memberikan pelayanan kesehatan baik preventif, kuratif, promotif, mau pun rehabilitatif kepada masyarakat kota $\mathrm{X}$.

$$
\text { Manajemen keuangan menurut }
$$

Setiawan (1996) mencakup aspek perencanaan, pelaksanaan dan pengawasan, yang berarti disamping perlu dilakukan evaluasi perencanaan dan realisasi, dan kontrol/pengawasan atas setiap perkiraan yang tercantum pada laporan keuangan RS $\mathrm{X}$.

Perlunya penerapan pengendalian manajemen, dimana menurut Bedford (1989). Sistem Pengendalian manajemen memiliki tahapan-tahapan sebagai berikut:

a. Pemilihan program-program yaitu proses memilih program spesifik untuk kegiatankegiatan organisasi

b. Penganggaran, merupakan rencna tindakannya, biasanya dinyatakan dalam satuan uang untuk periode, biasanya satu tahun

c. Operasi dan pengukuran, dilakukan dengan pencatatan tentang sumber daya yang secara aktual digunakan, dinyatakan dalam bentuk biaya, serta mengenai pendapatan yang secara aktual diperoleh

d. Pelaporan dan analisis, dimana sistem pengendalian manajemen berfungsi sebagai alat komunikasi, informasi yang dikomunikasikan terdiri atas data akuntansi dan non akuntansi, dihasilkan baik dari dalam mau pun dari luar organisasi. 


\section{KESIMPULAN DAN SARAN}

\section{Kesimpulan}

1. Adanya fluktuasi saldo kas dan setara kas disebabkan oleh fluktuasi pendapatan bersih, peningkatan saldo piutang, anggaran penerimaan dan pengeluaran yang mengahndalkan data historis, belum adanya evaluasi atas selisih dari anggaran dengan realisasi, tidak adanya kontrol yang memadai

2. Adanya fluktuasi saldo piutang disebabkan karena, fluktuasi pendapatan bersih, perubahan cara bayar dari bayar sendiri menjadi pasien jaminan/asuransi, belum adanya mekanisme penyaringan pasien jaminan/asuransi dan perorangan, lamanya proses penagihan piutang pasien jaminan/asuransi, sistem keuangan yang belum terintegrasi.

3. Adanya fluktuasi persediaan obat karena, mutasi obat untuk pasien di ruanganruangan belum tercatat dengan baik, surat pesanan dari farmasi belum direkonsiliasi dengan surat permintaan dari ruangan atau depo, dan tidak memakai mekanisme tender untuk pemilihan distributor.

\section{Saran}

1. Solusi pengelolaan Kas, Deposito dan Bank adalah perlunya dibuat anggaran kas melalui partisipasi aktif dari unit-unit produksi dan bukan tanggungjawab bagian keuangan semata, evaluasi selisih anggaran-realisasi, perlu dibuat prosedur permintaan kas, kontrol integrasi dari semua kasir

2. Solusi pengelolaan Piutang melalui pembenahan piutang dimulai dari titik awal dari penerimaan pasien, tersedianya informasi teknologi terkini status pasienpiutangnya

3. Solusi pengelolaan persediaan obat adalah, validitas pemakaian obat ruangan, dibuatnya peraturan yang jelas pada unit produksi untuk traksaksi yang terkait uang, pencatatan mengacu pada PSA.

\section{DAFTAR PUSTAKA}

Alkatiri, Ali dkk, 2001, Reformasi Perumah Sakitan, Grasindo

Amir Widjaja/Wibowo Sudirman, 1990, Apakah Strategix Planning diperlukan? Majalah Akuntansi, No. 9 TH IX September 
Azwar, Azrul, 1996, Analisa Laporan Keuangan, Lembaga Pendidikan dan Pengembangan, PERSI, Jakarta

Benjamin, P. Wahjudi, 1989, Akuntansi Dasawarsa 1990-an, Makalah Pada Program MM PPs FEUI

Bodnar, H. George, Hopwood, Accounting Information System, Edisi 5, Prentice-Hall International

Bedford, Dearden Anthony, 1989, Management Control System. 6th edition, Richard D, Irwin

Caplan, H Edwin, 1968, Behavioral Assumptions of Management Accounting, the Accounting Review, Juliy,h 342-362

Kresno, S, 1999, Aplikasi Pnelitian Kualitatif dalam Pemantauan dan Evaluasi Program kesehatan, FKMUI Bekerjasama dengan Pusat Data kesehatan, Depkes dan Kesos RI, 1999

Morse, J.M \& Field, P, A, 1995, Qualitative Research Method for Health Professionals 2nd Ed, Sage Publication International Educational \& Professional Publisher, Thousand Oaks, London

Notoadmodjo, Soekidjo, 1996, Metodologi kesehatan, Edisi 1, PT Rineka Cipta, Jakarta

Phelps, E. Charles, 1996, Health Economics, Harper Collins Publisher

Wibowo, Herman, 1999, Manajemen Kas: Pendekatan Efektif-Biaya, Majalah Akuntansi, No.3 Thn VIII, Ikatan Akuntan Indonesia, Maret 